\title{
Interference competition between alien invasive gammaridean species
}

\author{
M. C. van Riel · G. van der Velde • \\ A. bij de Vaate
}

Received: 17 January 2008/ Accepted: 18 August 2008/Published online: 25 June 2009

(C) The Author(s) 2009. This article is published with open access at Springerlink.com

\begin{abstract}
The relative abundances of gammaridean species in the river Rhine have profoundly changed since the invasion of Dikerogammarus villosus in 1994/1995. This study tested whether these changes in gammaridean dominance could have been determined by interspecific competition and unequal mortality, for example by intraguild predation (IGP). Single and two species tests have been carried out in aquariums provided with all substrata present in the main channel of the Rhine. Changes in substratum choice, increased swimming activity and increased mortality of a species were used as indicators of interspecific competition during interaction between gammaridean species. Interspecific competition and mortality between the most abundant invasive gammaridean species in the Rhine, viz. Gammarus tigrinus, Echinogammarus ischnus and
\end{abstract}

M. C. van Riel · G. van der Velde ( $\square)$

Department of Animal Ecology and Ecophysiology, Section Aquatic Animal Ecology, Institute for Wetland and Water Research, Radboud University Nijmegen,

Heyendaalseweg 135, 6525 AJ Nijmegen,

The Netherlands

e-mail: G.vandervelde@science.ru.nl

G. van der Velde

National Natural History Museum Naturalis, P.O. Box

9517, 2300 RA Leiden, The Netherlands

A. bij de Vaate

Waterfauna Hydrobiologisch Adviesbureau, Oostrandpark

30, 8212 AP Lelystad, The Netherlands
Dikerogammarus villosus were tested. In singlespecies experiments, G. tigrinus and D. villosus showed similar preferences for a stony substratum, whereas E. ischnus mostly occupied the water column. The two-species aquarium experiments indicated direct interference competition for substratum and unequal mortality between $G$. tigrinus and $D$. villosus, with $D$. villosus being the stronger competitor. Competitive stress was influenced by population density, was size-dependent and varied between the different types of substratum due to substratum choice. G. tigrinus did not show any behaviour indicative of interference competition in the presence of E. ischnus, and neither did E. ischnus or D. villosus in the presence of any of the other gammarideans. Swimming in the water layer may already enable E. ischnus to minimise its encounters with the stone-dwelling D. villosus and G. tigrinus. To maximise the encounters between E. ischnus and D. villosus, a fish (Lepomis gibbosus) was added to occupy the water layer during the aquarium experiments. E. ischnus showed a higher mortality in the presence of both $D$. villosus and fish, probably due to increased stress, as shelter opportunities to escape the predators had been minimised. The study shows that interference competition between gammaridean species can explain the replacement of the North American invader G. tigrinus by $D$. villosus in the river Rhine. E. ischnus and D. villosus both PontoCaspian invaders did not show interference competition in our experiments and co-exist in the Rhine. 
Keywords Competition - Bioinvasions · Gammaridea - Substratum choice . Predation

\section{Introduction}

Each river basin traditionally harbours a characteristic fauna, with species that remain endemic due to biogeographical barriers isolating the populations in the watersheds. Lifting these barriers by constructing waterways that link river systems leads to mixing of species and to new interactions between invasive and native species in the food web (Bij de Vaate et al. 2002; Van der Velde et al. 2002). Gammarideans have expanded their distribution all over Europe, enabled by the high connectivity level of Europe's large rivers and by intentional introductions, thus increasing their encounters (Bij de Vaate et al. 2002).

Invasions by species related to native species, as has occurred with gammarideans, can have a profound effect on a food web, as closely related species often occupy similar niches. These species can coexist under various circumstances, if resources are sufficiently available, population densities remain low (Van Overdijk et al. 2003; Van Riel et al. 2006a), the species are equally strong competitors or one of them is able to adjust its niche to avoid the other species in space or time. Limited availability of shared resources, which is most likely to occur during the population growth peak of an invasion, can result in interspecific competition. This can alter the functioning of food webs (Van der Velde et al. 2006) as it can have a huge impact on community structure.

Competition is most likely when species overlap completely in their needs for limited resources, and may result in species being replaced (Reynoldson and Bellamy 1970). The outcome of interspecific competition is not only determined by the limiting resource itself but also influenced by behavioural, physiological and morphological traits of the species involved, in relation to environmental conditions and anthropogenic disturbance (Dick et al. 1993; Carlton 1996; Moyle and Light 1996; Williamson and Fitter 1996a, b; Wisheu 1998; Van der Velde et al. 2002, 2006; Wijnhoven et al. 2003).
Competition mechanisms vary, as species can interact in different ways. Examples are pre-emptive competition, in which individuals occupy a unit of space and inhibit its occupation by others, and consumptive competition, in which a shared resource is being consumed. More direct competition is shown in interference competition, in which species harm one another by aggressive interaction while actively defending a unit of space (territorial competition), or by competitive interactions upon encounters (encounter competition) (Schoener 1983). In this paper, we use the term competition more broadly, defining it as a situation in which species use overlapping resources and may thus compete, regardless of differences in tactics of resource acquisition. An extreme form of encounter competition is intraguild predation (IGP), i.e., the killing and eating of species that use similar resources and are thus potential competitors (Polis et al. 1989), which has frequently been observed for gammarideans (Dick 1996; Dick et al. 1993; MacNeil et al. 2003). IGP may affect the distribution, population size, stability and resilience of species, reduce potential competition and promote the occurrence of alternative stable states (Polis et al. 1989; Dick and Platvoet 2000; Dick et al. 2002). Species suffering from interspecific competition may develop ways to escape this stress, for instance by avoiding encounters by reproducing at different times or by shifting their spatial niche.

Gammarideans stressed by interspecific competition increase their activity levels in terms of swimming, and seeking shelter (Garvey et al. 1994), and may eventually change their habitat utilisation. Competition for shelter can be size-mediated, giving the larger species an advantage in the competition for the larger shelter places and thus driving the competitively weaker species to smaller shelter areas. Competitively weaker species may be indirectly eliminated through predation by top predators (Garvey et al. 1994). Changes and replacements in gammaridean communities due to invasions by relatives have been frequently recorded (Pinkster et al. 1992; Dick and Platvoet 2000; Bollache et al. 2004; Jazdzewski et al. 2004; Meyer et al. 2005) and may have been determined by interspecific competition and IGP (Schoener 1983; MacNeil and Prenter 2000).

To the most successful invaders in the river Rhine belong amphipod crustaceans, which became dominant 
in numbers and biomass within a very short time and have a huge impact on the Rhine food web (Van der Velde et al. 2000, 2002; Haas et al. 2002; Leuven et al. 2009). The indigenous Gammarus pulex strongly decreased in numbers after the North-American species Gammarus tigrinus became abundant in 1982 and remained abundant for decades till the appearance of the Ponto-Caspian Dikerogammarus villosus (Van der Velde et al. 2000). In 1987, the Ponto-Caspian Chelicorophium curvispinum entered the Rhine through the Mittelland Canal in Germany and became dominant, covering the hard substrata with its muddy tubes. Echinogammarus ischnus also made its way through the Mittelland Canal to the Rhine in 1989. Since 1992, the Rhine has been connected to the Danube by the MainDanube canal, which facilitates invasions of the Rhine by Ponto-Caspian species (Bij de Vaate et al. 2002). The most recent mass invader, Dikerogammarus villosus is currently the largest amphipod species in the Rhine and is a strong, omnivorous predator (Dick and Platvoet 2000; Van der Velde et al. 2000, 2002; Dick et al. 2002; Van Riel et al. 2006b). Other alien or native gammarideans inhabiting the Rhine have remained present in low numbers, as is the case with E. ischnus and D. haemobaphes, both Ponto-Caspian invaders, or are found occasionally at times of high discharge, probably after being flushed out of the tributaries, as is the case with the native $G$. pulex, the probably early PontoCaspian invader G. roeseli and the North American Crangonyx pseudogracilis (Bij de Vaate and Klink 1995; Bij de Vaate et al. 2006).

In an earlier paper interspecific competition between native and invader gammaridean species occurring in the Rhine is described (Van Riel et al. 2007). The present study investigated various situations of interspecific competition between the three most abundant invasive gammaridean species occurring in the Rhine, to answer the following questions:

(a) Could interspecific competition have determined the varying success of the successive invading gammarideans Gammarus tigrinus, Echinogammarus ischnus and Dikerogammarus villosus?

(b) Are interactions between invasive gammarideans determined by interspecific competition, as indicated by mortality, swimming behaviour and substratum choice shifts? (c) Could the presence of a fish predator change the above-mentioned indicators of competition between gammaridean species?

(d) Is it likely that the limited habitat heterogeneity in the Rhine's main channel influence interspecific competition?

\section{Materials and methods}

Study site characteristics and invasion history

The Rhine is a large river ecosystem under various forms of anthropogenic stress, such as water pollution and salination (Van der Velde et al. 1990, 2006; Admiraal et al. 1993; Bij de Vaate et al. 2006). The floodplain is embanked with dikes and the main channel has been canalised, reducing its heterogeneity to two main biotopes, i.e., sandy streambeds and stony riverbanks and groynes (Admiraal et al. 1993). Water quality has improved lately by sanitation, but rehabilitation of the native fauna seems to be inhibited by the large numbers of invasive species present in the Rhine (Van der Velde et al. 2000, 2002).

Field studies

Biomonitoring has been carried out in the river Waal, a Rhine distributary, in the vicinity of the Dutch town of Nijmegen $\left(5^{\circ} 48^{\prime} \mathrm{E} ; 51^{\circ} 52^{\prime} \mathrm{N}\right)$, by sampling during the years 1992, 1993 and 2001. Macroinvertebrates were sampled monthly by sampling six groyne stones from a water depth of $2 \mathrm{~m}$ by means of a polyp-grab operated with a hydraulic crane from a ship. Macroinvertebrates were cautiously brushed off the stones, collected and preserved in $70 \%$ ethanol, subsequently sorted by species, and counted in the laboratory using a stereomicroscope. The total surface area of the stones was calculated from the areas of all sides of the stones, in order to quantify the densities of macroinvertebrate species per square metre of substratum.

\section{Aquarium experiments}

Aquarium experiments in the laboratory were used to study possible IGP and interspecific competition for 
substratum between the exotic gammaridean species D. villosus, G. tigrinus and E. ischnus. Interspecific predation, shifts in substratum choice and altered swimming behaviour after the addition of another species were assumed to indicate interspecific competition or IGP. The substrata used in these experiments reflected those occurring in the Rhine and provided the species with opportunities for shelter to various degrees. A series of experiments was carried out to study different situations of competition and to find out under what conditions gammarideans show interspecific competition and whether interspecific competition could be intensified by increasing densities or by introducing a top predator such as a fish. Although several fish species occurring in the Rhine have been identified as feeding on gammarideans (Kelleher et al. 1998, 2000) they could not be held in our aquaria for several reasons. Therefore, in this study, the pumpkinseed sunfish (Lepomis gibbosus) was used as the top predator because of its small size, its predatory behaviour with respect to macroinvertebrates including gamnmarideans (Van Kleef et al. 2008) and because this fish could be easily obtained from the aquarium shop. It is not occurring in the Rhine but functions in our experiments as a representative of any predatory fish.

Adult D. villosus (DV) and E. ischnus (EIS) were collected from stone substrata in the river Waal near Nijmegen $\left(5^{\circ} 48^{\prime} \mathrm{E}, 51^{\circ} 51^{\prime} \mathrm{N}\right)$. G. tigrinus (GT) was collected from Lake IJsselmeer $\left(5^{\circ} 32^{\prime} \mathrm{E}, 52^{\circ} 35^{\prime} \mathrm{N}\right)$. All specimens were kept separately, in aerated basins $(40 \times 40 \times 50 \mathrm{~cm})$ at $15^{\circ} \mathrm{C}$, with a $9 / 15 \mathrm{~h}$ dark/light regime, before being released into the experimental aquaria. The gammarideans were fed dead frozen chironomids during captivity.

The experiments were carried out in a climate room at $15^{\circ} \mathrm{C}$ with a $9 / 15 \mathrm{~h}$ dark/light regime $(236 \mathrm{~W} /$ 840 TLD lamps). Aquaria $(25 \times 25 \times 30 \mathrm{~cm})$ were filled with Rhine water and aerated. Four different types of Rhine substratum, i.e., one groyne stone $(\varnothing 14.4 \mathrm{~cm} \pm 1.5)$, pebbles ( $5.4 \mathrm{~cm} \pm 1.2$ ), gravel (Ø $2.5 \mathrm{~cm} \pm 1.0)$ and sand, were put into cups (Ø 11.5, $6.5 \mathrm{~cm}$ height), which were randomly placed in each aquarium. In single-species tests, 50 adult individuals of the same species (50 GT $(n=10), 50$ EIS $(n=14)$ or $50 \mathrm{DV}(n=14))$ were allowed to choose between substrata. After $24 \mathrm{~h}$, the cups with substrata were collected and the gammarideans inside each cup were counted and their body lengths measured. The gammarideans swimming in the water column were counted and measured as well and are referred to as 'free' in the figures. The substratum containing the largest number of specimens was considered to be the preferred substratum. In addition, the numbers of specimens that had died (undamaged dead individuals) or had been consumed (only remnants of individuals found) were counted. The experiment was repeated for three combinations: G. tigrinus with D. villosus, E. ischnus with D. villosus and $G$. tigrinus with E. ischnus. In these two-species experiments, specimens of G. tigrinus or E. ischnus were allowed to hide for $2 \mathrm{~h}$ before $D$. villosus were added. The following nine density combinations were tested: $50 \mathrm{GT}+25 \mathrm{DV}(n=10), 25 \mathrm{GT}+25 \mathrm{DV}$ $(n=10), 25 \mathrm{GT}+50 \mathrm{DV}(n=10), 25 \mathrm{GT}+25$ EIS $(n=10), 50 \mathrm{GT}+50 \mathrm{EIS}(n=2), 25 \mathrm{EIS}+25$ $\mathrm{DV}(n=14), 50 \mathrm{EIS}+1$ fish $(n=14), 50 \mathrm{DV}+1$ fish $(n=14), 25 \mathrm{EIS}+25 \mathrm{DV}+1$ fish $(n=12)$. Each experiment was repeated four times, using new individuals from the stock populations.

Echinogammarus ischnus (mean length $=1.07 \mathrm{~cm}$, $\mathrm{SD}=0.22$ ) used in the single-species experiments and in the two-species experiments with $D$. villosus had been collected in spring (April 2001) and were significantly smaller $(P<0.000, t$-test $)$ than the $E$. ischnus (mean length $=0.81 \mathrm{~cm}, \mathrm{SD}=0.25$ ) used in the twospecies experiments with $G$. tigrinus, which had been collected in summer (August 2001). The mean body length of $G$. tigrinus used in the different experiments was similar (length $=0.71 \mathrm{~cm}, \mathrm{SD}=0.20)(P>0.05$, $t$-test), just as for $D$. villosus (mean length $1.15 \mathrm{~cm}$, $\mathrm{SD}=0.23)(P>0.05, t$-test $)$.

Statistical analysis

The numbers of surviving specimens present on the various substrata and in the water column were analyzed for substratum choice patterns. Shifts in these patterns in the two-species experiments compared to the single-species experiments were assumed to indicate interspecific interactions. Differences in substratum choice patterns of the gammaridean species under different levels of competitive stress, caused by varying densities in the aquariums, were tested using a 2-way Generalised Linear Model for Poisson distribution (SAS 8.0). The substratum choice patterns that were derived from the surviving specimens present on the substratum types were 
analysed. A Poisson distribution was used in the model because the data were based on counts. A Games-Howell post hoc test (SPSS 11.5) was used to analyse any significant preference for any of the substratum types by a gammaridean species in an experiment.

The substratum choice patterns in the different aquarium experiments were clustered using Euclidean distances. The clustering was used to interpret similarities between the substratum choice patterns shown in the different aquarium experiments and not as statistical proof. Differences in body length between the gammarideans present on the various substrata within a specific treatment condition were tested in the aquarium experiments using a one-way ANOVA and a Games-Howell post hoc test on logtransformed data (SPSS 11.5). Differences in body length between individuals of species used in various aquarium experiments were tested using $t$-tests (SPSS 11.5). Intraspecific and interspecific differences in the substratum choice were tested using a paired $t$-test. Mortality rates of the specimens during the substratum choice experiments were compared using a oneway ANOVA with a Games-Howell post hoc test.

One-way ANOVA was also used to test the influence of different densities of prey and predators on intraguild predation between $D$. villosus and G. tigrinus. Differences between the two species in the numbers of specimens consumed were tested using a paired $t$-test.

\section{Results}

Field studies

Field observations show that the relative abundances of gammarideans in the main channel of the river Waal changed profoundly after the invasion by D. villosus (Fig. 1). Whereas G. tigrinus dominated the gammaridean community during 1992 and 1993, D. villosus had outnumbered G. tigrinus in 2001 , showing similar densities as G. tigrinus had before. In all of the years during this study, E. ischnus showed low densities, but the lowest densities were found during the years when D. villosus was present in large numbers. During these years, water temperature was similar but chlorophyll- $a$ availability decreased, as did the abundance of $C$. curvispinum. Despite this decrease, $C$. curvispinum still dominated the macroinvertebrate fauna on the stones in terms of numbers, with population peaks of around 40,000 specimens per square metre of substratum (Fig. 1).

Aquarium studies

In single-species tests, G. tigrinus and D. villosus preferred pebbles, whereas E. ischnus preferred swimming in the water layer rather than occupying the stone substratum (Table 1). All species disliked sand as a substratum (Fig. 2; Table 2). Changes in substratum choice patterns of a species in the presence of other species were observed in the two-species experiments (Tables 1, 3; Fig. 3) and were influenced by substratum type and by the presence of the other gammaridean species (Table 3). Such changes in substratum choice due to the presence of another gammaridean species occurred in most cases (Table 3, significant substratum $\times$ competition interaction). In the case of $G$. tigrinus in the presence of E. ischnus (2-way GLM, $P=0.87$ ), D. villosus in the presence of E. ischnus (2-way GLM, $P=0.32$ ) and E. ischnus in the presence of D. villosus (2-way GLM, $P=0.89$ ) the data as they show no significant shift are not presented. The largest shifts in substratum choice were observed for G. tigrinus in the presence of higher densities of $D$. villosus and of higher densities of E. ischnus, for E. ischnus in the presence of G. tigrinus, and for D. villosus in the presence of E. ischnus together with a fish (Tables 1, 2; Figs. 4, 5).

In the presence of D. villosus, G. tigrinus shifted from pebbles to gravel and sand. D. villosus remained most abundant on pebbles once it had established itself, showing no marked shifts in substratum occupation (Tables 1, 2, Fig. 4). It was particularly the smaller specimens of G. tigrinus (Fig. 6) which were found hiding in gravel and digging themselves into sand for shelter (1-way ANOVA, $P<0.001$; Games-Howell $P<0.001$ for body length of specimens on sand and gravel). A high level of predation on $G$. tigrinus by $D$. villosus occurred when the species were put together (Table 1; Fig. 7). Predation on G. tigrinus was greatest when the density of $G$. tigrinus was twice that of D. villosus. Predation on D. villosus was greatest in the single-species tests (Fig. 7), indicating cannibalism. 

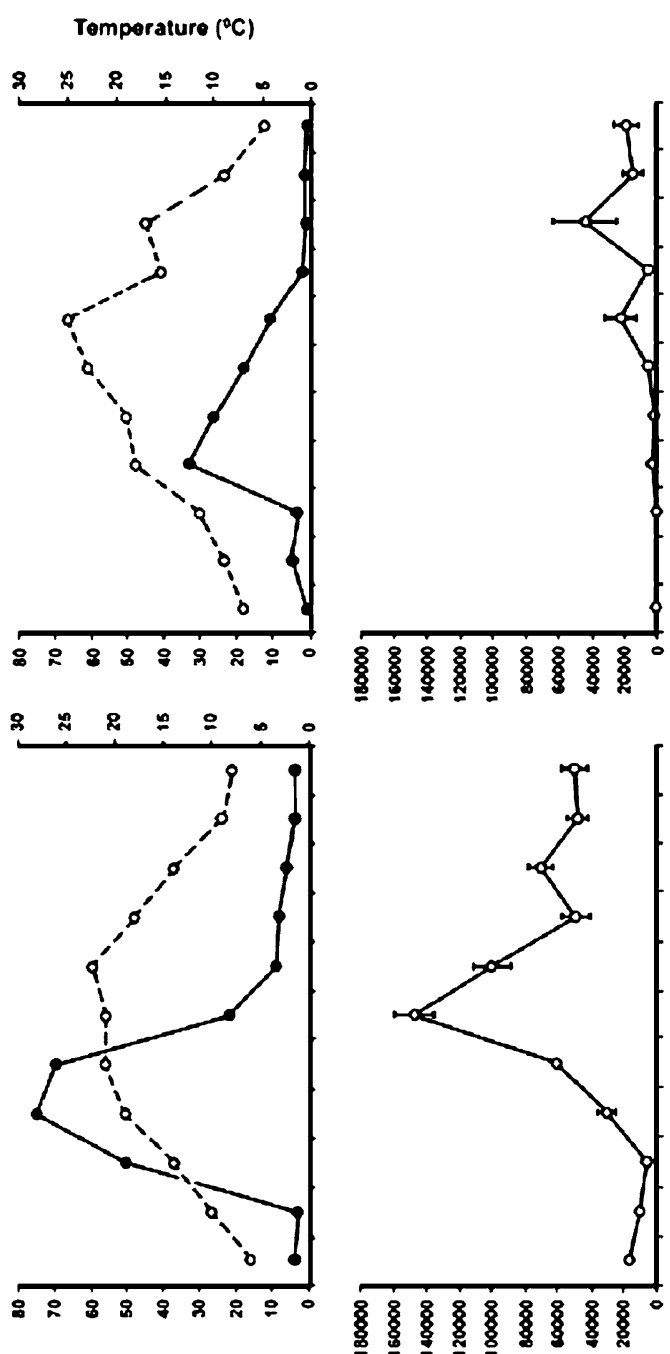

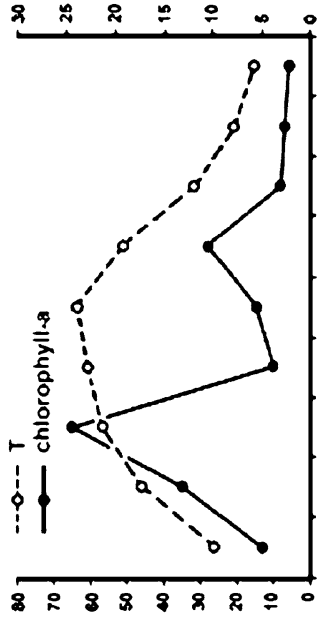

(, B Bi) e-11<4dosoly

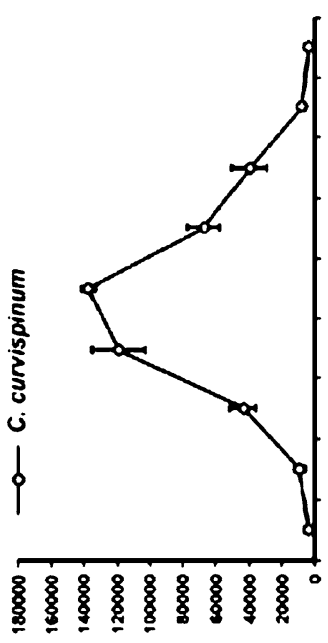

( 4 w) wnu!ds!nno :

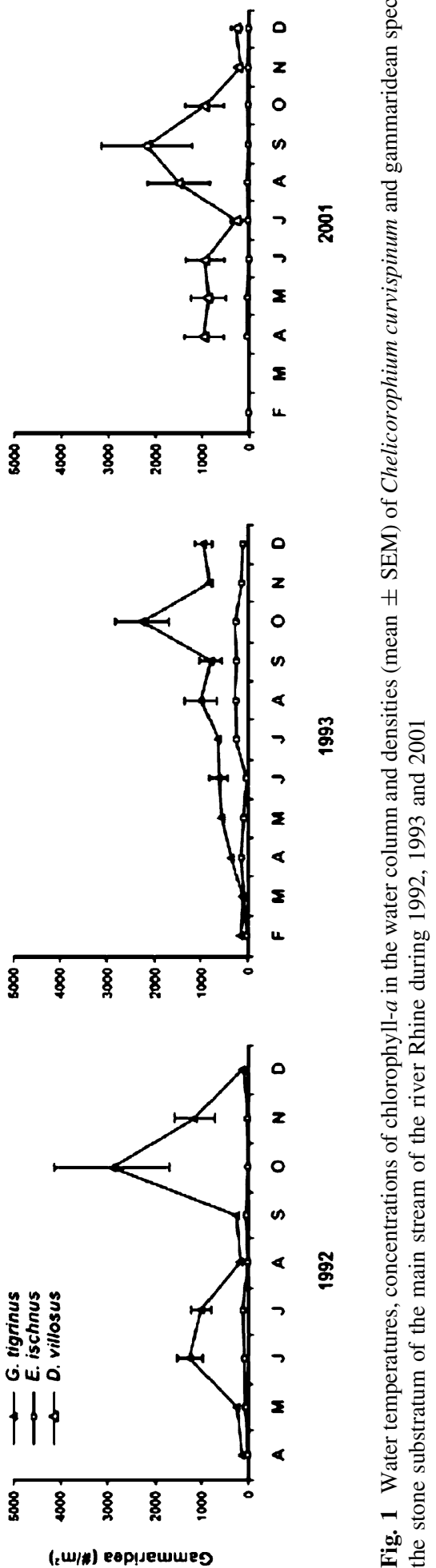


Table 1 Substratum choice patterns and mortality (mean\% \pm SEM) of Gammarus tigrinus (GT), Echinogammarus ischnus (EIS) and Dikerogammarus villosus (DV) in the various experiments

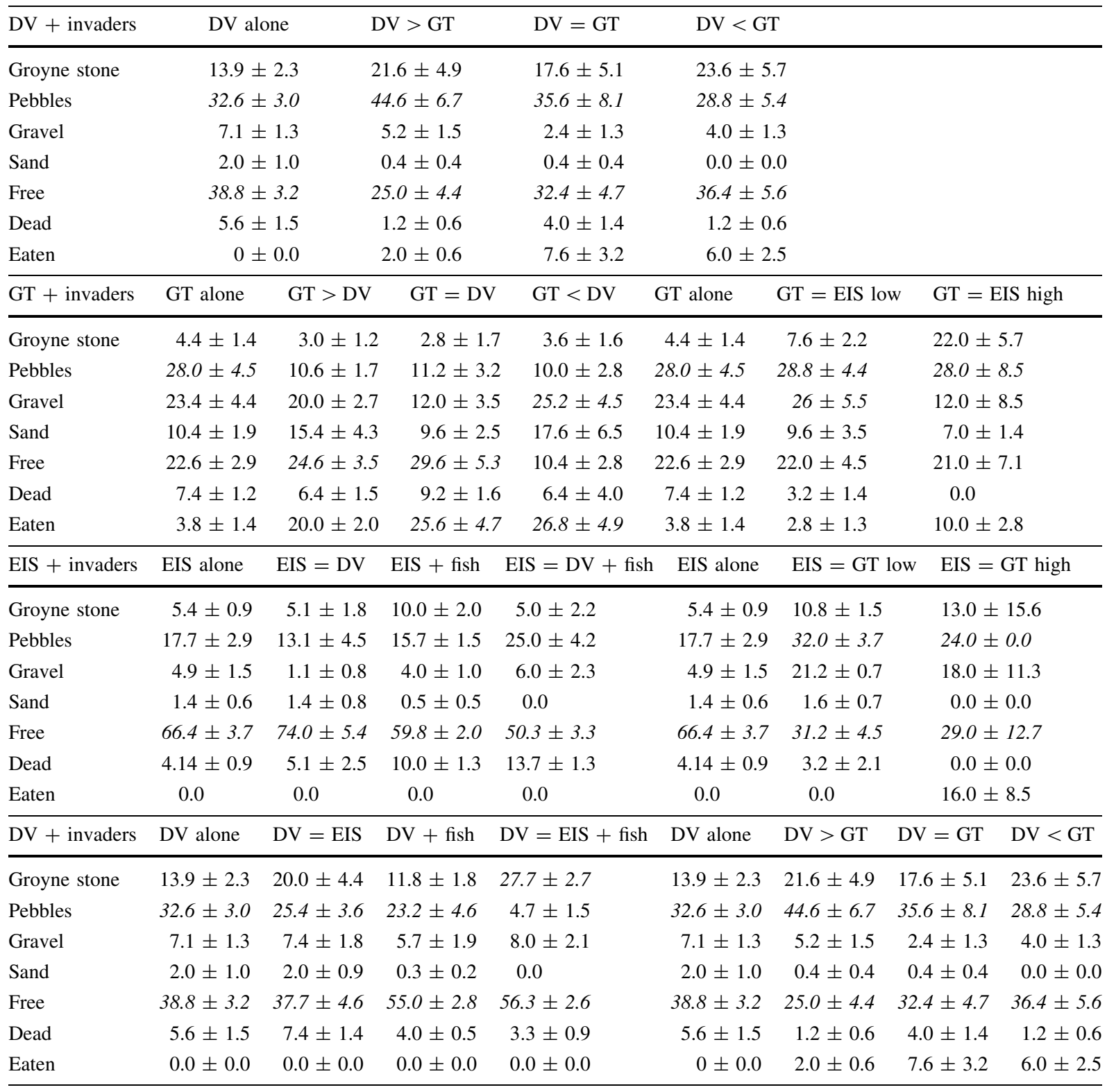

Preferred substrata are in italics

In the presence of G. tigrinus, E. ischnus was more abundant on the substratum than in the single-species tests, whereas G. tigrinus did not change its substratum choice pattern (Fig. 4; Tables 1, 2, 3). The species did not avoid each other but seemed to prefer the same substratum.

Neither D. villosus nor E. ischnus significantly changed their substratum choice in each other's presence (Table 2; 3; Fig. 5), and mortality did not increase (Table 1; Fig. 5), making direct competition between these invaders unlikely. When a top predator such as a fish was present in an experiment with both E. ischnus and D. villosus, E. ischnus suffered a slightly higher mortality than $D$. villosus ( $t$-test, $P=0.18$ ) (Fig. 5), and both species significantly changed their substratum choice patterns (Tables 2, 3; Fig. 5). 
Fig. 2 Substratum choice and mortality (mean \pm SEM) of Gammarus tigrinus (GT), Dikerogammarus villosus (DV) and Echinogammarus ischnus (EIS) in single species tests. Significant differences in a species' substratum choice are presented in Table 2
Table 2 Significant differences between substratum distribution patterns of gammarideans in aquarium studies (analysed by Games-Howell post hoc test)

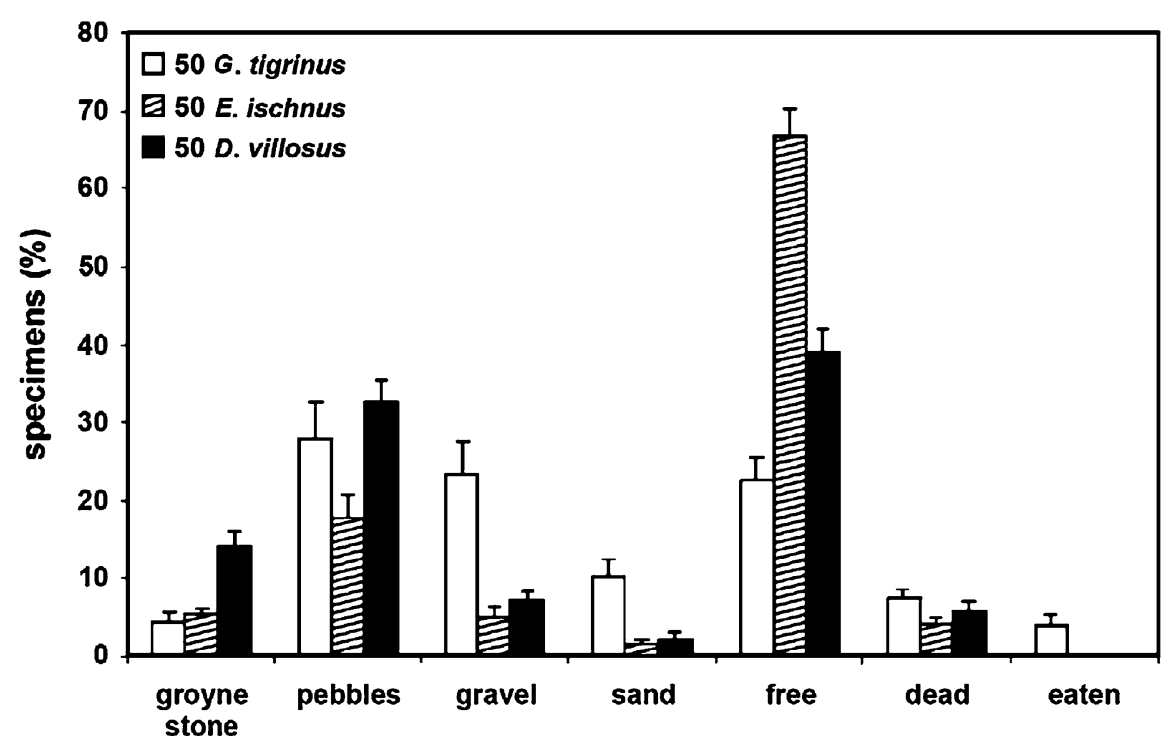

\begin{tabular}{|c|c|c|c|c|c|c|c|}
\hline Figure & Species & Experiment & Groyne stones & Pebbles & Gravel & Sand & Free \\
\hline 3 & G. tigrinus & $50 \mathrm{GT}$ & $\mathrm{B}$ & A & A & $\mathrm{B}$ & A \\
\hline 3 & E. ischnus & 50EIS & $\mathrm{C}$ & B & $\mathrm{CD}$ & $\mathrm{D}$ & A \\
\hline 3 & D. villosus & $50 \mathrm{DV}$ & $\mathrm{B}$ & A & $\mathrm{B}$ & $\mathrm{C}$ & A \\
\hline $4 a$ & G. tigrinus & $50 \mathrm{GT}$ & $\mathrm{B}$ & A & A & B & A \\
\hline $4 b$ & G. tigrinus & $25 \mathrm{GT}+50 \mathrm{DV}$ & $\mathrm{B}$ & $\mathrm{AB}$ & A & $\mathrm{AB}$ & A \\
\hline $4 a$ & D. villosus & $50 \mathrm{DV}$ & $\mathrm{B}$ & A & $\mathrm{B}$ & $\mathrm{C}$ & A \\
\hline $4 \mathrm{~b}$ & D. villosus & $25 \mathrm{DV}+50 \mathrm{GT}$ & A & A & B & B & A \\
\hline $4 \mathrm{c}$ & G. tigrinus & $50 \mathrm{GT}$ & $\mathrm{B}$ & A & A & B & A \\
\hline $4 \mathrm{c}$ & E. ischnus & 50EIS & $\mathrm{C}$ & B & $\mathrm{CD}$ & $\mathrm{D}$ & A \\
\hline $4 d$ & G. tigrinus & $25 \mathrm{GT}+25 \mathrm{EIS}$ & $\mathrm{B}$ & A & A & B & A \\
\hline $4 d$ & E. ischnus & $25 \mathrm{EIS}+25 \mathrm{GT}$ & $\mathrm{C}$ & A & $\mathrm{C}$ & $\mathrm{D}$ & $\mathrm{B}$ \\
\hline 6 & E. ischnus & $50 \mathrm{EIS}$ & $\mathrm{C}$ & $\mathrm{B}$ & $\mathrm{CD}$ & $\mathrm{D}$ & A \\
\hline 6 & E. ischnus & $25 \mathrm{EIS}+25 \mathrm{DV}$ & $\mathrm{BC}$ & $\mathrm{B}$ & $\mathrm{C}$ & $\mathrm{C}$ & A \\
\hline 6 & E. ischnus & 50 EIS + fish & $\mathrm{BC}$ & $\mathrm{B}$ & $\mathrm{C}$ & $\mathrm{D}$ & A \\
\hline 6 & E. ischnus & $25 \mathrm{EIS}+25 \mathrm{DV}+\mathrm{fish}$ & $\mathrm{C}$ & B & $\mathrm{C}$ & $\mathrm{C}$ & A \\
\hline 6 & D. villosus & $50 \mathrm{DV}$ & B & A & B & $\mathrm{C}$ & A \\
\hline 6 & D. villosus & $25 \mathrm{DV}+25 \mathrm{EIS}$ & $\mathrm{AB}$ & A & $\mathrm{BC}$ & $\mathrm{C}$ & A \\
\hline 6 & D. villosus & $50 \mathrm{DV}+\mathrm{fish}$ & $\mathrm{BC}$ & B & $\mathrm{CD}$ & $\mathrm{D}$ & A \\
\hline 6 & D. villosus & $25 \mathrm{DV}+25 \mathrm{EIS}+\mathrm{fish}$ & $\mathrm{B}$ & $\mathrm{CD}$ & $\mathrm{C}$ & $\mathrm{D}$ & A \\
\hline
\end{tabular}

\section{Discussion}

Invasive gammarideans have had a great impact on the macroinvertebrate community in the Rhine; the North American invader G. tigrinus dominated the Rhine for years and the relative abundance of gammarideans in the Rhine changed profoundly after the invasion of D. villosus in 1995 (Van der Velde et al. 2000, 2002; Van Riel et al. 2006b). Within 6 years, D. villosus had outnumbered G. tigrinus and dominated the gammaridean community. Interspecific competition has proved important in determining gammaridean communities (Schoener 1983; Polis et al. 1989; Dick 1996; Petren and Case 1996; Dick and Platvoet 2000; MacNeil and Prenter 2000; Abrams 2001; Van Overdijk et al. 2003), but so have 
Table 3 Influences of substratum type, interspecific relations and the interaction between interspecific relations and substratum type on the substratum choice pattern shown by gammaridean species in the presence of a potentially competitive invader species, analysed by means of a 2-way Generalised Linear Model for Poisson distribution (SAS 8.0)

\begin{tabular}{|c|c|c|c|c|c|c|c|}
\hline Substrate preferences of & Source & num DF & den DF & $F$ value & $\operatorname{Pr}>F$ & Chi-square & $\operatorname{Pr}>\mathrm{ChiSq}$ \\
\hline \multirow[t]{3}{*}{ G. tigrinus in the presence of $D$. villosus } & Substrate type & 4 & 180 & 20.84 & $<0.0001$ & 83.37 & $<0.0001$ \\
\hline & Competition & 3 & 180 & 18.68 & $<0.0001$ & 56.04 & $<0.0001$ \\
\hline & Substrate $\times$ competition & 12 & 180 & 3.18 & 0.0004 & 37.17 & 0.0001 \\
\hline \multirow[t]{3}{*}{ G. tigrinus in the presence of E. ischnus } & Substrate type & 4 & 90 & 16.19 & $<0.0001$ & 64.77 & $<0.0001$ \\
\hline & Competition & 1 & 90 & 14.54 & 0.0003 & 14.54 & 0.0001 \\
\hline & Substrate $\times$ competition & 4 & 90 & 0.31 & 0.8718 & 1.23 & 0.8726 \\
\hline \multirow[t]{3}{*}{ D. villosus in the presence of G. tigrinus } & Substrate type & 4 & 200 & 101.42 & $<0.0001$ & 405.67 & $<0.0001$ \\
\hline & Competition & 3 & 200 & 11.62 & $<0.0001$ & 34.86 & $<0.0001$ \\
\hline & Substrate $\times$ competition & 12 & 200 & 2.56 & 0.0036 & 30.67 & 0.0022 \\
\hline \multirow[t]{3}{*}{ D. villosus in the presence of E. ischnus } & Substrate type & 4 & 130 & 63.18 & $<0.0001$ & 252.7 & $<0.0001$ \\
\hline & Competition & 1 & 130 & 17.9 & $<0.0001$ & 17.9 & $<0.0001$ \\
\hline & Substrate $\times$ competition & 4 & 130 & 1.17 & 0.3265 & 4.68 & 0.3212 \\
\hline \multirow[t]{3}{*}{ D. villosus in the presence of fish } & Substrate type & 4 & 120 & 120.72 & $<0.0001$ & 482.88 & $<0.0001$ \\
\hline & Competition & 1 & 120 & 4.99 & 0.0273 & 4.99 & 0.0255 \\
\hline & Substrate $\times$ competition & 4 & 120 & 4.9 & 0.0011 & 19.6 & 0.0006 \\
\hline \multirow{3}{*}{$\begin{array}{l}\text { D. villosus in the presence of E. ischnus } \\
\text { and fish }\end{array}$} & Substrate type & 4 & 240 & 164.44 & $<0.0001$ & 657.77 & $<0.0001$ \\
\hline & Competition & 3 & 240 & 14.03 & $<0.0001$ & 42.09 & $<0.0001$ \\
\hline & Substrate $\times$ competition & 12 & 240 & 8.1 & $<0.0001$ & 97.19 & $<0.0001$ \\
\hline \multirow[t]{3}{*}{ E. ischnus in the presence of D. villosus } & Substrate type & 4 & 130 & 195.25 & $<0.0001$ & 780.99 & $<0.0001$ \\
\hline & Competition & 1 & 130 & 26 & $<0.0001$ & 26 & $<0.0001$ \\
\hline & Substrate $\times$ competition & 4 & 130 & 2.02 & 0.0954 & 8.08 & 0.0887 \\
\hline \multirow[t]{3}{*}{ E. ischnus in the presence of fish } & Substrate type & 4 & 120 & 131.42 & $<0.0001$ & 525.68 & $<0.0001$ \\
\hline & Competition & 1 & 120 & 22.13 & $<0.0001$ & 22.13 & $<0.0001$ \\
\hline & Substrate $\times$ competition & 4 & 120 & 3.06 & 0.0194 & 12.23 & 0.0157 \\
\hline \multirow{3}{*}{$\begin{array}{l}\text { E. ischnus in the presence of D. villosus } \\
\text { and fish }\end{array}$} & Substrate type & 4 & 240 & 316.35 & $<0.0001$ & 1265.41 & $<0.0001$ \\
\hline & Competition & 3 & 240 & 13.39 & $<0.0001$ & 40.16 & $<0.0001$ \\
\hline & Substrate $\times$ competition & 12 & 240 & 3.32 & 0.0002 & 39.87 & $<0.0001$ \\
\hline \multirow[t]{3}{*}{ E. ischnus in the presence of G. tigrinus } & Substrate type & 4 & 110 & 55.27 & $<0.0001$ & 221.07 & $<0.0001$ \\
\hline & Competition & 1 & 110 & 1.96 & 0.164 & 1.96 & 0.1612 \\
\hline & Substrate $\times$ competition & 4 & 110 & 14.14 & $<0.0001$ & 56.57 & $<0.0001$ \\
\hline
\end{tabular}

factors such as water temperature and ionic content (Wijnhoven et al. 2003), chlorophyll- $a$ availability (Rajagopal et al. 1999; Platvoet et al. 2006), the abundance of bulk prey species like $C$. curvispinum (Van Riel et al. 2006b) and alternative refuges, which are scarce in the main stream of the river Rhine, as macrophytes are absent and the substrata other than stones offer little shelter, resulting in frequent encounters between highly abundant invasive gammarideans with limited chances to escape competition (Van Riel et al. 2006b).
Whereas water temperatures were comparable during the 3 years this study was performed (1992, 1993 and 2001), both chlorophyll- $a$ and the abundance of C. curvispinum had decreased in 2001, which may have resulted in a reduced food availability for gammarideans (Van der Velde et al. 2000; Van Riel et al. 2006b). Despite its decreased densities, C. curvispinum remained dominant among the macroinvertebrate fauna on the stones in terms of numbers, with population peaks of around 40,000 specimens per square metre of substratum (Fig. 1) 


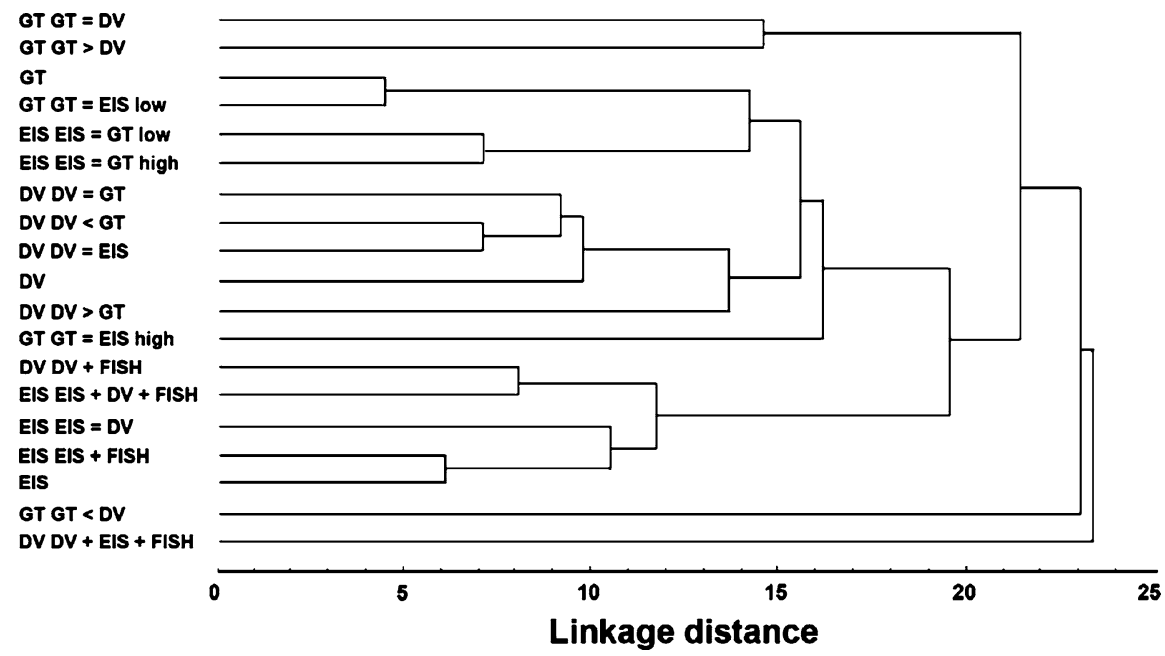

Fig. 3 Complete linkage of substratum choice patterns of the surviving specimens in the various aquarium experiments. Species are indicated by the following codes: GT = Gammarus tigrinus, $\mathrm{DV}=$ Dikerogammarus villosus and EIS $=$ Echinogammarus ischnus. The first two letters of the codes indicate the
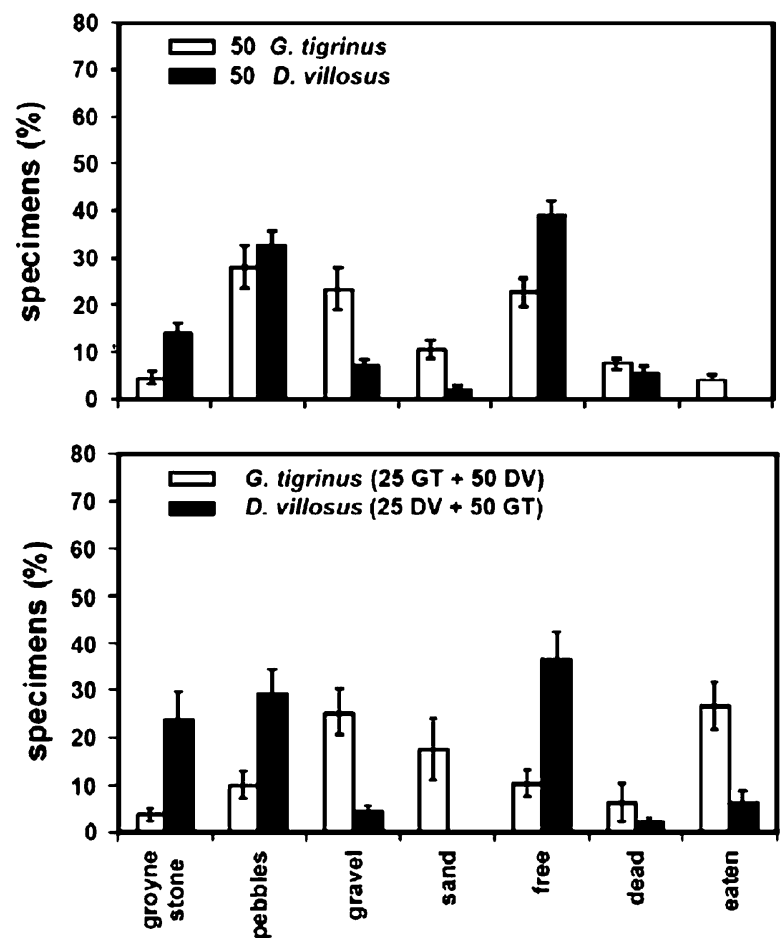

Fig. 4 Substratum occupation and mortality (mean \pm SEM) by Gammarus tigrinus (GT), Dikerogammarus villosus (DV) and Echinogammarus ischnus (EIS) in single and two species

(Van Riel et al. 2006b). If the 2001 decrease was large enough to limit C. curvispinum as a food resource for gammarideans, it may have intensified species which showed the choice pattern, while the following letters indicate the experimental combinations of the species and the densities at which the patterns were observed
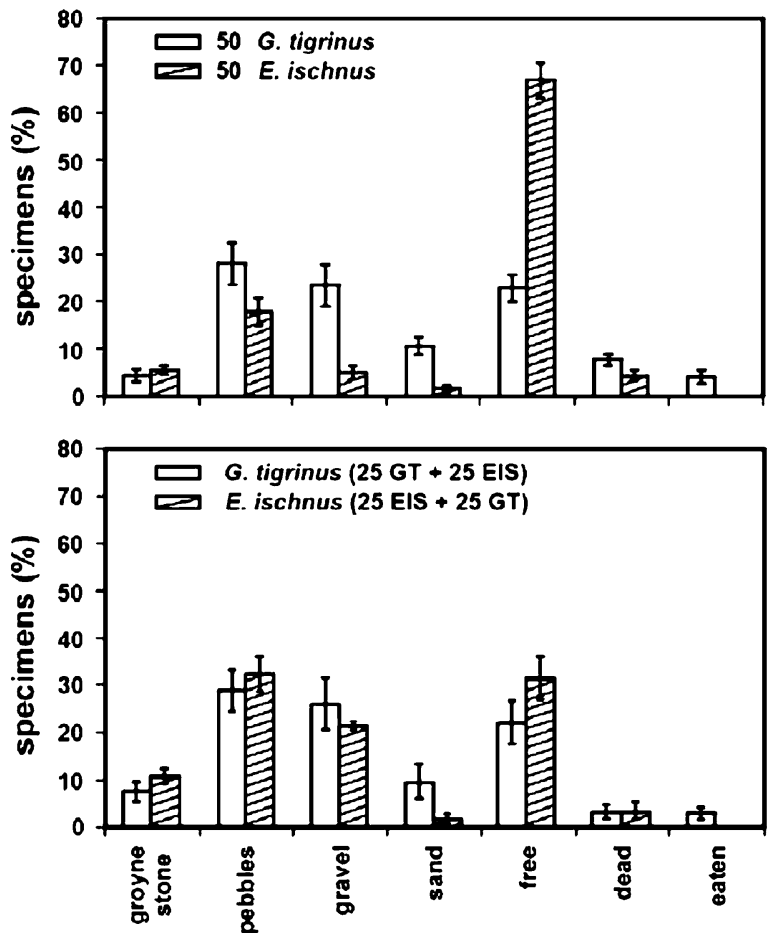

tests. Significant differences in a species' substratum choice are presented in Table 2

competition and predation between the abundant gammarideans. Before this hypothesis can be confirmed, however, IGP and interspecific competition 

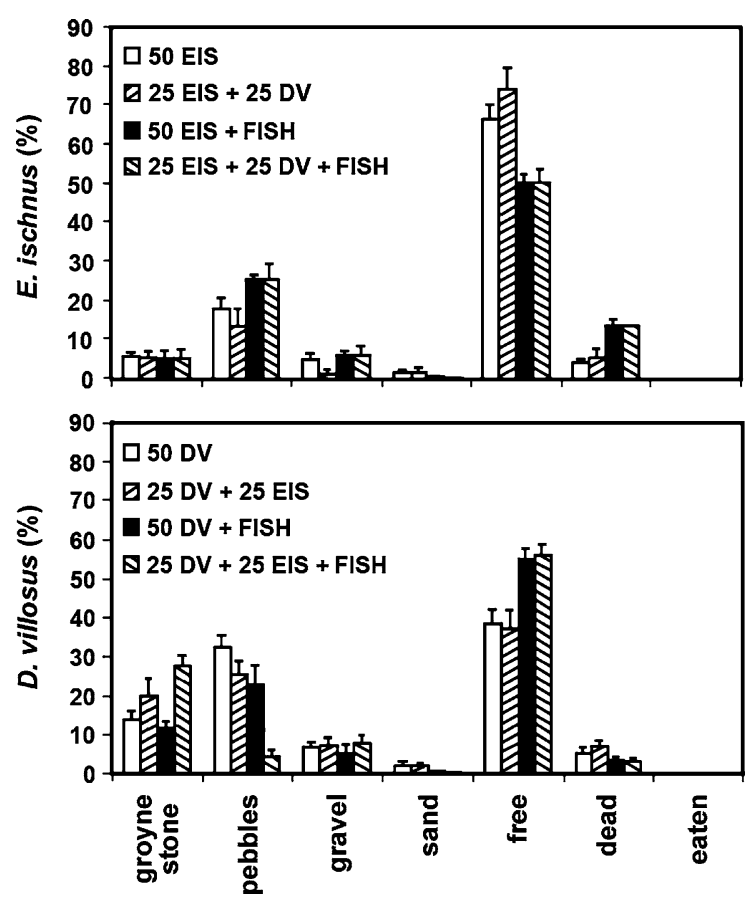

Fig. 5 Substratum occupation and mortality (mean \pm SEM) of Dikerogammarus villosus (DV) and Echinogammarus ischnus (EIS) in single and two species tests in the absence and in the presence of a predator (Lepomis gibbosus) in aquarium experiments. Significant differences for a specific density combination are displayed in Table 2 (Games Howell's multiple comparison test, $\alpha=0.05$ )

between invasive gammarideans in the Rhine must first be demonstrated, which was the goal of the present substratum choice experiments.

Our aquarium experiments showed shifts in substratum choice and alterations in swimming behaviour which indicated interspecific competition between gammaridean species. The substratum choices of G. tigrinus and D. villosus as tested in the singlespecies experiments, were found to be highly similar, probably resulting in a high encounter probability. Both species preferred mid-size stone substratum, disliked sand as a substratum, and regularly swam around in the water column. The aquarium experiments revealed that direct competition for substratum can occur between these two species, with $D$. villosus being the stronger competitor. Competitive stress was influenced by population density, and varied between the different types of substratum as a result of substratum choice. Interspecific competition seemed to take place by means of encounter competition and predation, as G. tigrinus was preyed upon increasingly in the presence of $D$. villosus and shifted its substratum choice to finer types of substratum, where it hid. The smaller specimens in particular fled to the finer substrata and even dug themselves into the sand.

The third abundant invasive gammaridean species in the Rhine, E. ischnus, primarily occupied the water column in the aquarium experiments and was therefore less likely to encounter the other invaders frequently. No behaviour indicative of competition was found for any species in the presence of E. ischnus, neither for E. ischnus in the presence of any of the other invaders. However, when a fish occupied the water column and the stone substratum was at the same time occupied by $D$. villosus, E. ischnus suffered higher mortality, which could be the result of increased stress, as shelter opportunities to escape from the predators were minimised.

The present study demonstrated different interactions between potential competitors. The two-species aquarium experiments showed species shifting their substratum choice, IGP by D. villosus on G. tigrinus, species altering swimming behaviour and increased competitive stress in the presence of a fish predator. On the other hand, our monitoring studies on stones in the main stream of the river Waal showed D. villosus to be a dominant species, with other gammarideans only occurring in low numbers. Of the two most important habitats, groyne stone riverbanks and sandy streambeds, gammarideans preferred the stones (Van Riel et al. 2006a, b). Increasing the heterogeneity of the ecosystem would provide weaker competitors with refuges to escape IGP by $D$. villosus and/or G. tigrinus (Van Riel et al. 2004). In times of limited resources, interspecific competition for substratum and mutual predation can determine the colonisation success of a gammaridean species in the ecosystem.

Based on field observations and experimental studies the following conclusions could be drawn: (a) Interspecific competition and unequal mortality could partly have determined the varying success of the gammaridean invaders in the Rhine, (b) Shifts in mortality, swimming behaviour and substratum choice do indicate interactions between invasive gammarideans, which are determined by IGP and interspecific competition, (c) When refuges are limited, fish predators intensify interspecific competition between gammarideans, and (d) The limited 

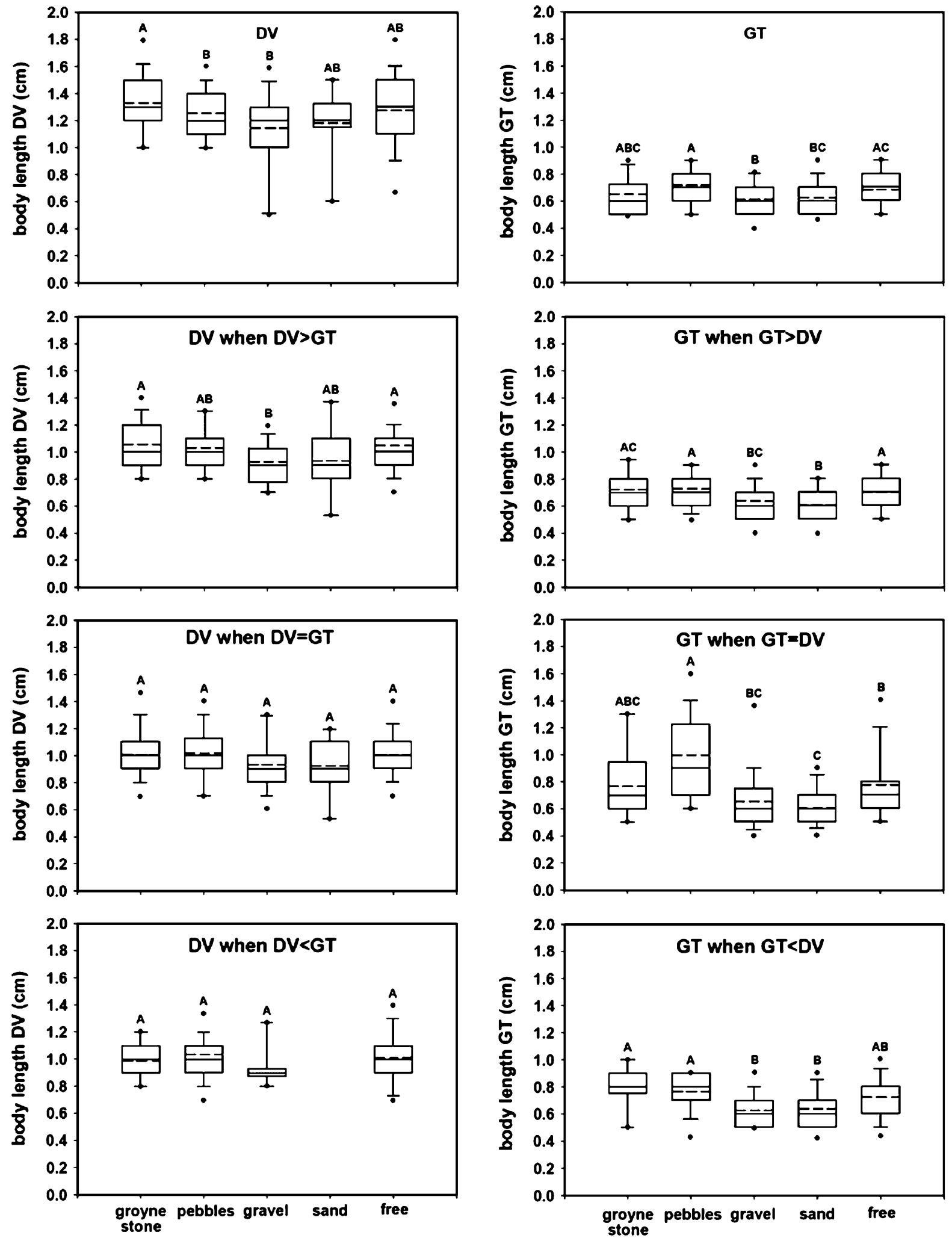
4Fig. 6 Body lengths of Dikerogammarus villosus (DV, a-d) and Gammarus tigrinus (GT, e-h) specimens present on the different substrata in the aquarium experiments. Levels of interspecific competition were manipulated by varying the population densities: $50 \mathrm{DV}$ or GT $(\mathbf{a}, \mathbf{e}), 50 \mathrm{DV}$ or GT +25 of the other species $(\mathbf{b}, \mathbf{f}), 25 \mathrm{DV}$ or GT +25 of the other species $(\mathbf{c}, \mathbf{g})$, and $25 \mathrm{DV}$ or GT +50 of the other species (d, h). Different letters indicate significant differences between the body lengths of specimens of the same species present on different substrata. Whisker-box plots represent $25-75 \%$ of the values. Bars indicate $5-95 \%$ of the values. Dots refer to 1 or $99 \%$. Mean values are indicated by a dashed line in the boxes, whereas a solid line in a box refers to median values

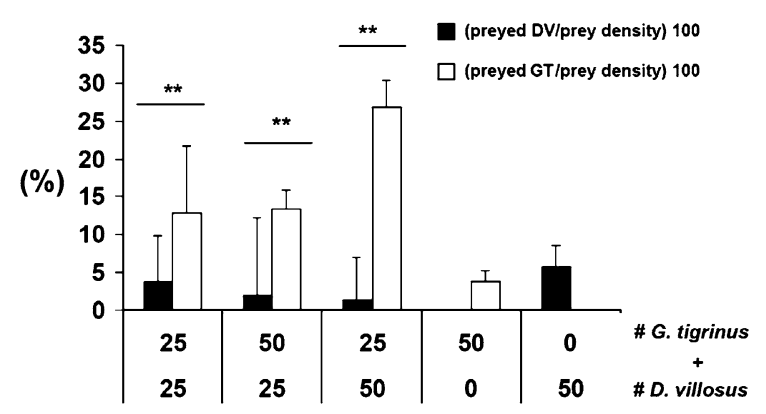

Fig. 7 Predation (mean \pm SEM) between Gammarus tigrinus (GT) and Dikerogammarus villosus (DV) when the species are present in different densities. The $x$-axis shows the numbers of specimens of each species present in the aquarium experiments. Different letters indicate significant differences within the same experiment. Bars marked with asterisks indicate significant differences between the different treatments. Significance levels: $* * * P<0.001, * * P<0.01, * P<0.05$

number of biotopes stimulates competition for stones in the Rhine's main channel. More shelter options could increase the opportunities for potentially competitive species to co-exist.

Acknowledgments The authors would like to thank Marij Orbons and Martin Versteeg for valuable assistance.

Open Access This article is distributed under the terms of the Creative Commons Attribution Noncommercial License which permits any noncommercial use, distribution, and reproduction in any medium, provided the original author(s) and source are credited.

\section{References}

Abrams PA (2001) Describing and quantifying interspecific interactions: a commentary on recent approaches. Oikos 94:209-218

Admiraal W, Van der Velde G, Smit H et al (1993) The rivers Rhine and Meuse in the Netherlands: present state and signs of ecological recovery. Hydrobiologia 265:97-128
Bij de Vaate A, Klink A (1995) Dikerogammarus villosus Sowinsky (Crustacea: Gammaridae), a new immigrant in the Dutch part of the Lower Rhine. Lauterbornia 20: 51-54

Bij de Vaate A, Jazdzewski K, Ketelaars HAM et al (2002) Geographical patterns in range extension of Ponto-Caspian macroinvertebrate species in Europe. Can J Fish Aquat Sci 59:1159-1174

Bij de Vaate A, Breukel R, Van der Velde G (2006) Long-term developments in ecological rehabilitation of the main distributaries in the Rhine Delta: fish and macroinvertebrates. Hydrobiologia 565:229-242

Bollache L, Devin S, Wattier R et al (2004) Rapid range extension of the Ponto-Caspian amphipod Dikerogammarus villosus in France: potential consequences. Arch Hydrobiol 160:57-66

Carlton JT (1996) Patterns, process, and prediction in marine invasion ecology. Biol Conserv 78:97-106

Dick JTA (1996) Post-invasion communities of Lough Neagh, Northern Ireland: influences of habitat selection and mutual predation. J Anim Ecol 65:756-767

Dick JTA, Platvoet D (2000) Invading predatory crustacean Dikerogammarus villosus eliminates both native and exotic species. Proc Roy Soc Lond B 267:977-983

Dick JTA, Montgomery I, Elwood RW (1993) Replacement of the indigenous amphipod Gammarus duebeni celticus by the introduced $G$. pulex: differential cannibalism and mutual predation. J Anim Ecol 62:79-88

Dick JTA, Platvoet D, Kelly DW (2002) Predatory impact of the freshwater invader Dikerogammarus villosus (Crustacea: Amphipoda). Can J Fish Aquat Sci 59:1078-1084

Garvey JE, Stein RA, Thomas HM (1994) Assessing how fish predation and interspecific prey competition influence a crayfish assemblage. Ecology 75:532-547

Haas G, Brunke M, Streit B (2002) Fast turnover in dominance of exotic species in the Rhine River determines biodiversity and ecosystem function: an affair between amphipods and mussels. In: Leppäkoski E, Gollasch S, Olenin S (eds) Invasive aquatic species of Europe: distribution, impacts and management. Kluwer Academic Publishers, Dordrecht, pp 426-432

Jazdzewski K, Konopacka A, Grabowski M (2004) Recent drastic changes in the gammarid fauna (Crustacea, Amphipoda) of the Vistula River deltaic system in Poland caused by alien invaders. Div distrib 10:81-87

Kelleher B, Bergers PJM, Van den Brink FWB et al (1998) Effects of exotic amphipod invasions on fish diet in the Lower Rhine. Arch Hydrobiol 143:363-382

Kelleher B, Van der Velde G, Giller PS et al (2000) Dominant role of exotic invertebrates, mainly Crustacea, in diets of fish in the lower Rhine River. In: Von Vaupel Klein JC, Schram FR (eds). The biodiversity crisis and Crustacea. Proc. 4th Int. Crust. Congr., Amsterdam, The Netherlands. 20-24 July, 1998, vol 2. A.A. Balkema, Rotterdam. Crustacean Issues 12:35-46

Leuven RSEW, Van der Velde G, Baijens I et al (2009) The river Rhine: a global highway for dispersal of aquatic invasive species. Biol Invasions. doi:10.1007/s10530009-9491-7

MacNeil C, Prenter J (2000) Differential microdistributions and interspecific interaction in coexisting native and 
introduced Gammarus spp. (Crustacea: Amphipoda). J Zool Soc Lond 251:377-384

MacNeil C, Bigsby E, Dick JTA et al (2003) Differential physico-chemical tolerances and intraguild predation among native and invasive amphipods (Crustacea); a field study. Arch Hydrobiol 156:165-179

Meyer A, Kaschek N, Meyer EI (2005) The effect of low flow and stream drying on the distribution and relative abundance of the alien amphipod, Echinogammarus berilloni (Catta, 1878) in a karstic stream system (Westphalia, Germany). Crustaceana 77:909-922

Moyle PB, Light T (1996) Biological invasions of fresh water: empirical rules and assembly theory. Biol Conserv 78: 149-161

Petren K, Case TJ (1996) An experimental demonstration of exploitation competition in an ongoing invasion. Ecology 77:118-132

Pinkster S, Scheepmaker M, Platvoet D et al (1992) Drastic changes in the amphipod fauna (Crustacea) of Dutch inland waters during the last 25 years. Bijdr Dierk 61: 193-204

Platvoet D, Dick JTA, Konijnendijk N et al (2006) Feeding on micro-algae in the invasive Ponto-Caspian amphipod $\mathrm{Di}$ kerogammarus villosus (Sowinsky, 1894). Aquat Ecol 40: 237-245

Polis GA, Myers CA, Holt RD (1989) The ecology and evolution of intraguild predation: potential competitors that eat each other. Ann Rev Ecol Syst 20:297-330

Rajagopal S, Van der Velde G, Paffen BGP et al (1999) Life history and reproductive biology of the invasive amphipod Corophium curvispinum (Crustacea: Amphipoda) in the Lower Rhine. Arch Hydrobiol 144:305-325

Reynoldson TB, Bellamy LS (1970) The establishment of interspecific competition in field populations, with an example of competition in action between Polycelis nigra (Müll.) and $P$. tenuis (Ijima) (Turbellaria, Tricladida). Proceedings for advanced study Institute on Dynamics Numbers and Populations, pp 282-297

Schoener TW (1983) Field experiments on interspecific competition. Am Nat 122:240-284

Van der Velde G, Van Urk G, Van den Brink FWB (1990) Rein Rijnwater, een sleutelfactor in chemisch oecosysteemherstel. In: Hekstra GP, Van Linden FJM et al (eds) Flora en fauna chemisch onder druk. Pudoc, Wageningen, pp 231-266

Van der Velde G, Rajagopal S, Kelleher B et al (2000) Ecological impact of crustacean invaders: general considerations and examples from the Rhine River. Crustac Issues $12: 3-33$

Van der Velde G, Nagelkerken I, Rajagopal S (2002) Invasions by alien species in inland freshwater bodies in Western
Europe: the Rhine Delta. In: Leppäkoski E, Gollasch S, Olenin $\mathrm{S}$ et al (eds) Invasive species of Europe: distribution, impacts and management. Kluwer Academic Publishers, Dordrecht, pp 360-372

Van der Velde G, Rajagopal S, Kuyper-Kollenaar M et al (2006) Biological invasions: concepts to understand and predict a global threat. In: Bobbink R, Beltman B, Verhoeven JTA, Whigham DF (eds) Wetlands: functioning, biodiversity conservation and restoration, Ecological Studies, vol 191. Springer-Verlag, Berlin, pp 61-90

Van Kleef H, Van der Velde G, Leuven RSEW et al (2008) Pumpkinseed sunfish (Lepomis gibbosus) invasions facilitated by introductions and nature management strongly reduce macroinvertebrate abundance in isolated water bodies. Biol Invasions 10:1481-1490

Van Overdijk CDA, Grigorovich IA, Mabee T et al (2003) Microhabitat selection by the invasive amphipod Echinogammarus ischnus and native Gammarus fasciatus in laboratory experiments and in Lake Erie. Freshw Biol 48: 567-578

Van Riel MC, Van der Velde G, Bij de Vaate A (2004) Alien amphipod invasions in the river Rhine due to river connectivity: a case of competition and mutual predation. In: Douben N, van Os AG (eds) Proceedings NCR-days 2003, dealing with floods within constraints. Netherlands Centre for River Studies, Delft, pp 51-53

Van Riel MC, Van der Velde G, Bij de Vaate A (2006a) To conquer and persist: colonization and population development of the Ponto-Caspian amphipods Dikerogammarus villosus and Chelicorophium curvispinum on bare stone substrate in the main channel of the River Rhine. Arch Hydrobiol 166:23-39

Van Riel MC, Van der Velde G, Rajagopal S et al (2006b) Trophic relationships in the Lower Rhine food web during invasion and after establishment of the Ponto-Caspian invader Dikerogammarus villosus. Hydrobiologia 565: 39-58

Van Riel MC, Healy EP, Van der Velde G et al (2007) Interference competition among native and invader amphipods. Acta Oecol 31:282-289

Wijnhoven S, Van Riel MC, Van der Velde G (2003) Exotic and indigenous freshwater gammarid species: physiological tolerance to water temperature in relation to ionic content of the water. Aquat Ecol 37:151-158

Williamson M, Fitter A (1996a) The characters of successful invaders. Biol Conserv 78:163-170

Williamson M, Fitter A (1996b) The varying success of invaders. Ecology 77:1661-1666

Wisheu IC (1998) How organisms partition habitats: different types of community organization can produce identical patterns. Oikos 83:246-258 